Abstracta Iranica Abstracta Iranica

Revue bibliographique pour le domaine irano-aryen

Volume 32-33 | 2013

Comptes rendus des publications de 2009-2010

\title{
Y. Avishur, M. Heltzer. Sheshbazzar and Zerubbabel and Their Activities in the Last Third of the VI Century B.C.
}

\section{Astrid Nunn}

\section{(2) OpenEdition}

1 Journals

\section{Édition électronique}

URL : http://journals.openedition.org/abstractairanica/40178

DOI : 10.4000/abstractairanica.40178

ISSN : 1961-960X

Éditeur :

CNRS (UMR 7528 Mondes iraniens et indiens), Éditions de l'IFRI

\section{Édition imprimée}

Date de publication : 1 décembre 2013

ISSN : 0240-8910

Référence électronique

Astrid Nunn, «Y. Avishur, M. Heltzer. Sheshbazzar and Zerubbabel and Their Activities in the Last Third of the VI Century B.C. 》, Abstracta Iranica [En ligne], Volume 32-33 | 2013, document 30, mis en ligne le 01 juillet 2016, consulté le 04 octobre 2020. URL : http://journals.openedition.org/abstractairanica/40178 ; DOI : https://doi.org/10.4000/abstractairanica.40178

Ce document a été généré automatiquement le 4 octobre 2020.

Tous droits réservés 


\title{
Y. Avishur, M. Heltzer. Sheshbazzar and Zerubbabel and Their Activities in the Last Third of the VI Century B.C.
}

\author{
Astrid Nunn
}

\section{RÉFÉRENCE}

Y. Avishur, M. Heltzer. «Sheshbazzar and Zerubbabel and Their Activities in the Last Third of the VI Century B.C. ». Trans. 38, 2009, p. 99-117.

Sheshbazzar et Zerubbabel sont connus du texte araméen d'Ezra (5.14). Les AA. essaient de circonscrire les activités exactes de ces deux personnages et de déterminer leur rôle dans le gouvernement de la Judée au début de l'époque achéménide en analysant la terminologie administrative dans le texte d'Ezra, des textes grecs et le cylindre de Cyrus. Il en ressort que Zerubbabel était peut-être gouverneur de Judée.

\section{AUTEURS}

\section{ASTRID NUNN}

Université de Munich 